\title{
Long Term Effect of Integrated Nutrient Management on Secondary and Micronutrient of Alluvial Soils
}

\author{
Hena Parven ${ }^{1}$, Sunil Kumar ${ }^{1}$, Shweta Shambhavi ${ }^{1}$, Sanjay Kumar ${ }^{2}$, \\ Raju Kumar ${ }^{1}$ and Dipti Kumari ${ }^{1}$ \\ ${ }^{1}$ Department of Soil science and Agricultural Chemistry, Bihar Agricultural University, \\ Sabour, Bhagalpur 813210 (Bihar) India \\ ${ }^{2}$ Department of Agronomy, Bihar Agricultural University, Sabour, \\ Bhagalpur 813210 (Bihar) India \\ *Corresponding author
}

\section{A B S T R A C T}

\section{Keywords}

Long-term, INM, Shulphur, Zinc, Copper, Iron and Manganese

Article Info

Accepted:

15 January 2020

Available Online:

10 February 2020
The present work studied the data from a 34 years old long-term rice-wheat cropping sequence to evaluate the effects of integrated nutrient management (INM) on secondary and micronutrient under alluvial soil. The treatment included three organic sources viz. FYM, wheat straw (WS) and green manuring (GM) with Sesbania aculeate replacing 25\% and $50 \%$ of the optimum $\mathrm{N}$ during kharif season, treatment replacing $50 \% \mathrm{~N}$ through organic manure were given $100 \% \mathrm{RDF}$ in wheat while those receiving $25 \% \mathrm{~N}$ replacement in rice got only $75 \% \mathrm{RDF}$ in wheat. The results indicated that the replacement of $50 \%$ and $25 \% \mathrm{~N}$ of RDF to rice through organics either FYM/GM/ WS, significantly augment the DTPA-Zn, Cu, Fe \&Mn, available S and boron (B) content of post-harvest soil. It has been found that the integrated nutrient management increased the soil DTPA extractable $\mathrm{Zn}$ from $38-75 \%$, Cu $38-72 \%$, Fe $27-53 \%$, Mn $14-57 \%$, Available S $68-95 \%$, and hot water soluble B $93-160 \%$, than $100 \%$ RDF over a period of 34 years continuous cultivation might be due to the prominent contribution of INM leads to maintain the soil heath and it developed inherent capacity of soil as compare to sole mineral fertilization.

\section{Introduction}

Long-term fertilizer treatments provide valuable figures on impact of endless cropping and intensive fertilization on soil properties. Secondary and micronutrients are essential for the growth of plants and animals and deficiencies in soil not only limit the crop production but also have negative effects on human nutrition and health (Govindaraj et al.,
2011). Similarly, excessive agro-ecosystem inputs of micronutrients such as iron $(\mathrm{Fe})$, manganese $(\mathrm{Mn})$, copper $(\mathrm{Cu})$, and zinc $(\mathrm{Zn})$, which are heavy metals, can possibly lead to toxicity in plants and animals and consequently pose a threat to human health through the food chain (Westfall et al., 2005; Soriano-Disla et al., 2010). Continuous use of high analysis fertilizers and restricted supply of organic manures was leads of secondary 
and micronutrient deficiencies in soil and plants. The overall deficiency of micronutrient in Indian soil was found to be 47 per cent for $\mathrm{Zn}, 2$ per cent for $\mathrm{Cu}, 13$ per cent for Fe and 4 per cent for Mn (Sakal and Singh, 2001). Chemical fertilizers alone are unable to maintain secondary and micronutrients in soil (Subba Rao and Srivastava 1998). Removal of sulphur by crops in India is about $1.26 \mathrm{mt}$ whereas; its replenishment through fertilizers is only about $0.76 \mathrm{mt}$ (Tiwari and Gupta, 2006), Sulphur can play its role as yield and quality driver nutrient in crop production when it is applied in the soil wisely. The original geological substrate and subsequent geochemical land pedogenic regimes determine total levels of secondary and micronutrients in soils, but their total contents are rarely indicative of plant availability, which is also influenced by soil $\mathrm{pH}$, organic-matter content, adsorptive surfaces, and other physical, chemical, and biological factors in the rhizosphere. Thus, its availability in a given soil can also be strongly affected by fertilization practices. For example, long-term applications of inorganic nitrogen $(\mathrm{N})$ and phosphorus $(\mathrm{P})$ fertilizers reportedly result in depletion of soil available $\mathrm{S}, \mathrm{Zn}, \mathrm{Fe}, \mathrm{Mn}, \mathrm{Cu}$ and $\mathrm{B}$ in the plow layer, while incorporation of organic manure significantly increases contents of $\mathrm{S}, \mathrm{Zn}, \mathrm{Fe}$, $\mathrm{Mn}, \mathrm{Cu}$ and $\mathrm{B}$ in soils. Gao et al., (2000) found that manure is a better source of available $\mathrm{Fe}, \mathrm{Mn}$ and $\mathrm{Zn}$ than synthetic fertilizers, but manure applications accelerated the depletion of available $\mathrm{Cu}$ on a purple paddy soil in southwestern China after 9 years of fertilization. In contrast, in northern Italy, high liquid manure inputs reportedly increase risks of copper contamination on silty clay loam soils (Mantovi1 et al., 2003). The application of organic materials is fundamentally important in that they supply various kinds of secondary and micronutrient; improve soil fertility and productivity(Suzuki, 1997). Clearly, there are urgent needs to understand the effects of current practices on secondary and micronutrients in key agricultural regions such as the Indo-Gangetic plane of alluvial soils to identify the most efficient practices for managing them. Therefore, the study presented here evaluated the long term effect of integrated nutrient management on secondary and micronutrient of alluvial soils.

\section{Materials and Methods}

The present study was carried out during 2017-18 in a permanent plot experiment established at Bihar Agricultural College Research Farm $\left(25^{\circ} 23^{\prime} \mathrm{N}, 8^{\circ} 07^{\prime} \mathrm{E}\right.$ and 37.19m.S.L), Sabour, Bhagalpur, Bihar, India under IFS scheme started from 1984 comprising four replication and twelve treatment permutations. The treatment included three organic sources viz. FYM, wheat straw (WS) and green manuring (GM) with sesbania aculeate replacing $25 \%$ and $50 \%$ of the optimum $\mathrm{N}$ during kharif season, treatment replacing $50 \% \mathrm{~N}$ through organic manure were given $100 \%$ RDF in wheat while those receiving $25 \% \mathrm{~N}$ replacement in rice got only $75 \% \mathrm{RDF}$ in wheat. Thus it was making six INM treatment permutations, which were assessed against $100 \%$ RDF along with unfertilized absolute control.The required amount of FYM, wheat straw and green manure (Sesbania aculata) was applied 3 weeks before rice transplanting as per treatment to substitute a specified amount of N. The FYM, wheat straw and Sesbania aculata used in this experiment contain 0.50, 0.25 and $0.53 \% \mathrm{~N}$, respectively. The initial physico-chemical properties of the experimental soil is Ustochrept clayey soil having $\mathrm{pH} 7.24$, EC 0.24 , organic carbon $0.46 \%$, available $\mathrm{N} 246 \mathrm{~kg} / \mathrm{ha}$, available $\mathrm{P}_{2} \mathrm{O}_{5}$ $23.60 \mathrm{~kg} / \mathrm{ha}$ and available $\mathrm{K}_{2} \mathrm{O} \quad 155 \mathrm{~kg}$ /ha.The FYM, GM and WS were incorporated into the field by cross discing. Puddling was done at the time of transplanting the rice 
nursery. The average annual rainfall is about 500 to $550 \mathrm{~mm}$, most of which is received during the rainy seasons. The climate of the tract is typically semi-arid climate and scarcity of water.

Soil samples were collected from 0 to $15 \mathrm{~cm}$ soil layers from all the replications after harvesting of the rabi crop in May 2018. The soil samples were analyzed for: DTPA extractable- Zn, Cu, Fe \& Mn. 005 M DTPA, $0.01 \mathrm{M}$ Calcium Chloride and $0.1 \mathrm{M}$ Triethanolamine (TEA) at $\mathrm{pH}$ (7.3) ((Lindsey and Norvell, 1978). Hot water soluble B determined by Azomethalin-H colorimetric method ((Wolf 1974), Available Sulphur by Turbidimetric method (Chesnin and Yien, 1950).

\section{Results and Discussion}

Indian agriculture during the past 50 years has achieved a fourfold growth in food production by adopting modern agricultural practices. The availability of fertilizer responsive, high yielding varieties (HYV) of rice and wheat has made it possible to produce $15-20 \mathrm{t} \mathrm{ha}^{-1}$ year $^{-1}$ of biomass drymatter.

Initially, this became possible by using nitrogenous $(\mathrm{N})$ fertilisers alone, as the soil could provide all other essential nutrients needed by plants. However, within a few years, the nutrient reserves in soil were gradually exhausted and it was no longer possible to sustain higher yields even by applying both $\mathrm{N}$ and phosphorus (P) (Kanwar and Randhawa, 1974; Singh, 1988). Thus, in areas of high cropping intensity, deficiencies of secondary nutrients and micronutrients were frequently observed in cereal, oilseed, pulse and vegetable crops, which became critical in obtaining and sustaining higher crop production over the years (Singh, 2001; Singh et al., 2004).

\section{DTPA-extractable Zn}

The significant changes were recorded in the status of DTPA-extractable Zn content of soil over a period of 34 years due to various treatment integration and the results showed (Table-2.) that the extractable zinc content increased from $0.83-1.49 \mathrm{mg} \mathrm{kg}^{-1}$ with various combination of inorganic and organic nutrient management practices. The DTPA-extractable zinc content $\left(1.49 \mathrm{mg} \mathrm{kg}^{-1}\right)$ of soil highest value was obtained with $\mathrm{T}_{6}-50 \%$ NPK of $\mathrm{RDF}+50 \% \mathrm{~N}$ through FYM in rice crop and $100 \%$ NPK of RDF in wheat crop applied which was significantly superior over all the treatments like $\mathrm{T}_{7}\left(1.27 \mathrm{mg} \mathrm{kg}^{-1}\right), \mathrm{T}_{8}(1.25 \mathrm{mg}$ $\left.\mathrm{kg}^{-1}\right), \mathrm{T}_{11}\left(1.19 \mathrm{mg} \mathrm{kg}^{-1}\right), \mathrm{T}_{9}\left(1.14 \mathrm{mg} \mathrm{kg}^{-1}\right), \mathrm{T}_{1}$ $\left(0.92 \mathrm{mg} \mathrm{kg}^{-1}\right), \mathrm{T}_{2} \& \mathrm{~T}_{12}\left(0.88 \mathrm{mg} \mathrm{kg}^{-1}\right), \mathrm{T}_{3}$ $\left(0.87 \mathrm{mg} \mathrm{kg}^{-1}\right), \mathrm{T}_{5}\left(0.86 \mathrm{mg} \mathrm{kg}^{-1}\right)$ and $\mathrm{T}_{4}(0.83$ $\left.\mathrm{mg} \mathrm{kg}^{-1}\right)$ except statistically similar treatment $\mathrm{T}_{10}\left(1.31 \mathrm{mg} \mathrm{kg}^{-1}\right)$.

Imbalanced application of inorganic fertilizer decreased DTPA-extractable Zn contents in soil over control. Lowest DTPA-extractable Zn $\left(0.83 \mathrm{mg} \mathrm{kg}^{-1}\right)$ was recorded in $\mathrm{T}_{4}-75 \%$ NPK of RDF in both crops. It might be due to nonstop use of only $\mathrm{N}, \mathrm{P}, \mathrm{K}$ fertilizers and mining of these micronutrients due to intensive cultivation of rice-wheat cropping sequence under the absence of any organic sources, it is necessities to regular use of organic fertilizer to maintain micronutrient status of soils.

Different research studies showed that addition of organic matter helps in accumulation of $\mathrm{Zn}$ in its available fraction due to its decomposition in the soil. $\mathrm{H}$ followed by).However, higher amount of organic matter favors decrease in the available form of $\mathrm{Zn}$ through chelation. FYM beneficial effect either complexion or mobilization of native Zn (Singh, 2007 and Sawarkar et al., 2010). 


\section{DTPA-extractable Cu}

The significant effect of the organic manure was recorded in the status of DTPAextractable $\mathrm{Cu}$ varied from $1.48-3.24 \mathrm{mg} / \mathrm{kg}$ due to various organic and inorganic management treatments. The results showed that significantly superior of extractable $\mathrm{Cu}$ was noted under in $\mathrm{T}_{6} 50 \% \mathrm{~N}-\mathrm{FYM}(3.24$ $\mathrm{mg} / \mathrm{kg}$ ) and statically at par with $\mathrm{T}_{7} 25 \% \mathrm{~N}$ FYM $\quad(3.00 \quad \mathrm{mg} / \mathrm{kg}), \quad \mathrm{T}_{9} \quad 25 \% \mathrm{~N}-\mathrm{WS}(2.86$ $\mathrm{mg} / \mathrm{kg}), \mathrm{T}_{10} 50 \% \mathrm{~N}-\mathrm{GM}(2.84 \mathrm{mg} / \mathrm{kg})$ and $\mathrm{T}_{8}$ $50 \% \mathrm{~N}-\mathrm{WS}(2.72 \mathrm{mg} / \mathrm{kg})$ over in $\mathrm{T}_{2}-50 \%$ NPK $(1.48 \mathrm{mg} / \mathrm{kg})$. In present study DTPAextractable $\mathrm{Cu}$ status decreased after application of inorganic fertilizer alone. Perusal of data revealed that in table (2). Lowest DTPA-extractable $\mathrm{Cu}$ was recorded in $\mathrm{T}_{2}-50 \%$ NPK $(1.48 \mathrm{mg} / \mathrm{kg})$. Available $\mathrm{Cu}$ contains increase may be ascribed to reduction in the redox-potential of the soil with the addition of organic sources which led to more release of micronutrients in an available form in the soil as compared with the application of chemical fertilizers only. Increment of DTPA-extractable $\mathrm{Cu}$ may be associated with the chelating action of organic sources (FYM, GM and WS) that are liberated due to decomposition of organic source that advantages in availability of micronutrients through the prevention of some particular processes like fixation, oxidation, precipitation and leaching (Dhaliwal et al., 2019, Dhaliwal et al., 2010 and walia et al., 2010).

\section{DTPA-extractable Fe}

The combined application of inorganic fertilizer and organic manure was found significantly changes in the status of DTPAextractable $\mathrm{Fe}$ in soil of post-harvest of wheat crop. The results revealed that DTPAextractable Fe content increased from 24.11 to $37.03 \mathrm{mg} \mathrm{kg}^{-1}$ (Table 2) in amongst various treatments. Highest extractable $\mathrm{Fe}$ was noted under in $\mathrm{T}_{6}-50 \%$ N-FYM $(37.03 \mathrm{mg} / \mathrm{kg})$ and statically at par with $\mathrm{T}_{7}-25 \% \mathrm{~N}-\mathrm{FYM}(35.72$ $\mathrm{mg} / \mathrm{kg}), \mathrm{T}_{8}-50 \% \mathrm{~N}-\mathrm{WS}$ in $(34.45 \mathrm{mg} / \mathrm{kg}), \mathrm{T}_{10^{-}}$ $50 \% \mathrm{~N}-\mathrm{GM}(33.38 \mathrm{mg} / \mathrm{kg}), \mathrm{T}_{9}-25 \% \mathrm{~N}-\mathrm{WS}$ $(31.85 \mathrm{mg} / \mathrm{kg}), \mathrm{T}_{11}-25 \% \mathrm{~N}-\mathrm{GM}(30.65 \mathrm{mg} / \mathrm{kg})$ over $\mathrm{T}_{1}-(29.25)$.Lowest DTPA-extractable $\mathrm{Fe}$ was recorded in $\mathrm{T}_{5}-100 \%$ NPK $(24.11 \mathrm{mg} / \mathrm{kg})$. In soil Fe cycle associated with decomposition of organic matter. Release of $\mathrm{Fe}$ due to Weathering of minerals is a very slow process governed mainly by $\mathrm{pH}$ and $\mathrm{O}_{2}$ concentration and by the dissolutionprecipitation phenomena (Mengel, 1994 and Lindsay, 1988). It was observed that, the rate of weathering of these minerals could be accelerated by the activities of living organisms (Baker and Banfield, 2003, Hansel et al., 2004 and Liu et al., 2006).

\section{DTPA- extractable Mn}

The data on DTPA-extractable Mn after harvest of wheat crop is presented in Table 2. DTPA-extractable Mn ranged between from 11.93 to $18.78 \mathrm{mg} / \mathrm{kg}$ between various combination of inorganic and organic nutrient management treatment. DTPA-extractable Mn was found significantly superior in $T_{6}$ $50 \%$ N-FYM $(18.78 \mathrm{mg} / \mathrm{kg})$ and followed by $\mathrm{T}_{10} 50 \% \quad \mathrm{~N}-\mathrm{GM}, \mathrm{T}_{7}-25 \% \quad \mathrm{~N}-\mathrm{FYM} \quad(15.25$ $\mathrm{mg} / \mathrm{kg}), \mathrm{T}_{11} 25 \% \quad \mathrm{~N}-\mathrm{GM}, \mathrm{T}_{8} 50 \% \quad \mathrm{~N}-\mathrm{WS}$ $(13.76 \mathrm{mg} / \mathrm{kg})$ and $\mathrm{T}_{9}-25 \% \mathrm{~N}-\mathrm{WS}(13.56$ $\mathrm{mg} / \mathrm{kg})$ over $\mathrm{T}_{5^{-}}(11.93 \mathrm{mg} / \mathrm{kg})$. Graded doses of chemical fertilizers also decreased the DTPA-extractable Mn contents in soil over control and graded dose of organic manure. Lowest DTPA-extractable Mn was observed in $\mathrm{T}_{5}-100 \%$ NPK in both crops $(11.93 \mathrm{mg} / \mathrm{kg})$, All the treatments where 50\% NPK, 75\% NPK and farmer practices in both crops was applied through inorganic fertilizer showed lower DTPA-extractable $\mathrm{Mn}$ in soil compared to the $\mathrm{T} 1\left(14.00 \mathrm{mg} \mathrm{kg}^{-1}\right)$. 
Table.1 Different treatment combinations in the long-term experiment

\begin{tabular}{|c|c|c|}
\hline Treatments & Rice & Wheat \\
\hline $\mathbf{T}_{1}$ & Control & Control \\
\hline $\mathbf{T}_{2}$ & $50 \%$ RD of NPK through fertilizer & $50 \%$ RD of NPK through fertilizer \\
\hline $\mathbf{T}_{\mathbf{3}}$ & $50 \%$ RD of NPK through fertilizer & $100 \%$ RD of NPK through fertilizer \\
\hline $\mathbf{T}_{4}$ & $75 \%$ RD of NPK through fertilizer & $75 \%$ RD of NPK through fertilizer \\
\hline $\mathbf{T}_{\mathbf{5}}$ & $100 \%$ RD of NPK through fertilizer & $100 \%$ RD of NPK through fertilizer \\
\hline $\mathbf{T}_{6}$ & $\begin{array}{l}50 \% \mathrm{RD} \text { of NPK through fertilizer }+ \\
50 \% \mathrm{~N} \text { through FYM }\end{array}$ & $100 \%$ RD of NPK through fertilizer \\
\hline $\mathbf{T}_{7}$ & $\begin{array}{l}75 \% \mathrm{RD} \text { of NPK through fertilizer }+ \\
25 \% \mathrm{~N} \text { through FYM }\end{array}$ & $75 \%$ RD of NPK through fertilizer \\
\hline $\mathbf{T}_{8}$ & $\begin{array}{l}50 \% \mathrm{RD} \text { of NPK through fertilizer }+ \\
50 \% \mathrm{~N} \text { through wheat straw }\end{array}$ & $100 \%$ RD of NPK through fertilizer \\
\hline $\mathbf{T}_{9}$ & $\begin{array}{l}75 \% \mathrm{RD} \text { of NPK through fertilizer }+ \\
25 \% \mathrm{~N} \text { through wheat straw }\end{array}$ & $75 \%$ RD of NPK through fertilizer \\
\hline $\mathbf{T}_{10}$ & $\begin{array}{l}50 \% \mathrm{RD} \text { of NPK through fertilizer }+ \\
50 \% \mathrm{~N} \text { through green manure }\end{array}$ & $100 \%$ RD of NPK through fertilizer \\
\hline $\mathbf{T}_{11}$ & $\begin{array}{l}75 \% \mathrm{RD} \text { of NPK through fertilizer }+ \\
25 \% \mathrm{~N} \text { through green manure }\end{array}$ & $75 \%$ RD of NPK through fertilizer \\
\hline $\mathbf{T}_{12}$ & Farmer's practice $\left(\mathrm{N}_{70} \mathrm{P}_{30} \mathrm{~K}_{10}\right)$ & Farmer's practice $\left(\mathrm{N}_{80} \mathrm{P}_{30} \mathrm{~K}_{15}\right)$ \\
\hline
\end{tabular}

Table.2 Effect of long-term integrated nutrient management on DTPA-Extractable micronutrients of soil after $34^{\text {th }}$ years of rice-wheat system

\begin{tabular}{|c|c|c|c|c|}
\hline Treatment & $\begin{array}{c}\text { DTPA-Zn } \\
\left(\mathbf{m g ~ k g}^{-1}\right)\end{array}$ & $\begin{array}{c}\text { DTPA-Cu } \\
\left(\mathbf{m g ~ k g}^{-1}\right)\end{array}$ & $\begin{array}{c}\text { DTPA-Fe } \\
\left(\mathbf{m g ~ k g}^{-1}\right)\end{array}$ & $\begin{array}{l}\text { DTPA-Mn } \\
\left(\mathbf{m g ~ k g}^{-\mathbf{1}}\right)\end{array}$ \\
\hline $\mathrm{T}_{1}$ & 0.92 & 2.12 & 29.25 & 14.00 \\
\hline $\mathrm{T}_{2}$ & 0.88 & 1.48 & 27.47 & 13.12 \\
\hline $\mathrm{T}_{3}$ & 0.87 & 2.06 & 26.20 & 12.69 \\
\hline $\mathrm{T}_{4}$ & 0.83 & 1.80 & 25.87 & 12.06 \\
\hline $\mathrm{T}_{5}$ & 0.86 & 1.94 & 24.11 & 11.93 \\
\hline $\mathrm{T}_{6}$ & 1.49 & 3.24 & 37.03 & 18.78 \\
\hline $\mathrm{T}_{7}$ & 1.27 & 3.00 & 35.72 & 15.25 \\
\hline $\mathrm{T}_{8}$ & 1.25 & 2.72 & 34.45 & 13.76 \\
\hline $\mathrm{T}_{9}$ & 1.14 & 2.86 & 31.85 & 13.56 \\
\hline $\mathrm{T}_{10}$ & 1.31 & 2.84 & 33.38 & 15.37 \\
\hline $\mathrm{T}_{11}$ & 1.19 & 2.16 & 30.65 & 14.24 \\
\hline $\mathrm{T}_{12}$ & 0.88 & 1.42 & 27.65 & 13.62 \\
\hline $\mathbf{S ~ E m} \pm$ & $\mathbf{0 . 0 7}$ & $\mathbf{0 . 1 7}$ & $\mathbf{2 . 3 8}$ & $\mathbf{1 . 0 3}$ \\
\hline $\mathbf{C . D}(\mathbf{P}=\mathbf{0 . 0 5})$ & $\mathbf{0 . 2 0}$ & $\mathbf{0 . 4 9}$ & $\mathbf{7 . 0 3}$ & $\mathbf{3 . 0 3}$ \\
\hline & & & & \\
\hline
\end{tabular}


Table.3 Effect of long-term integrated nutrient management on available Boron (B) and Sulphur (S) of soil after $34^{\text {th }}$ year of rice-wheat system

\begin{tabular}{|c|c|c|}
\hline Treatment & Available B(mg/kg) & AvailableS (mg/kg) \\
\hline $\mathrm{T}_{1}$ & 0.51 & 9.75 \\
\hline $\mathrm{T}_{2}$ & 0.47 & 9.50 \\
\hline $\mathrm{T}_{3}$ & 0.40 & 8.96 \\
\hline $\mathrm{T}_{4}$ & 0.36 & 8.87 \\
\hline $\mathrm{T}_{5}$ & 0.30 & 7.78 \\
\hline $\mathrm{T}_{6}$ & 0.78 & 15.16 \\
\hline $\mathrm{T}_{7}$ & 0.71 & 13.81 \\
\hline $\mathrm{T}_{8}$ & 0.63 & 13.12 \\
\hline $\mathrm{T}_{9}$ & 0.61 & 12.83 \\
\hline $\mathrm{T}_{10}$ & 0.67 & 13.83 \\
\hline $\mathrm{T}_{11}$ & 0.58 & 13.34 \\
\hline $\mathrm{T}_{12}$ & 0.35 & 9.10 \\
\hline S Em \pm & 0.06 & 0.89 \\
\hline C.D $(P=0.05)$ & 0.17 & 2.64 \\
\hline
\end{tabular}

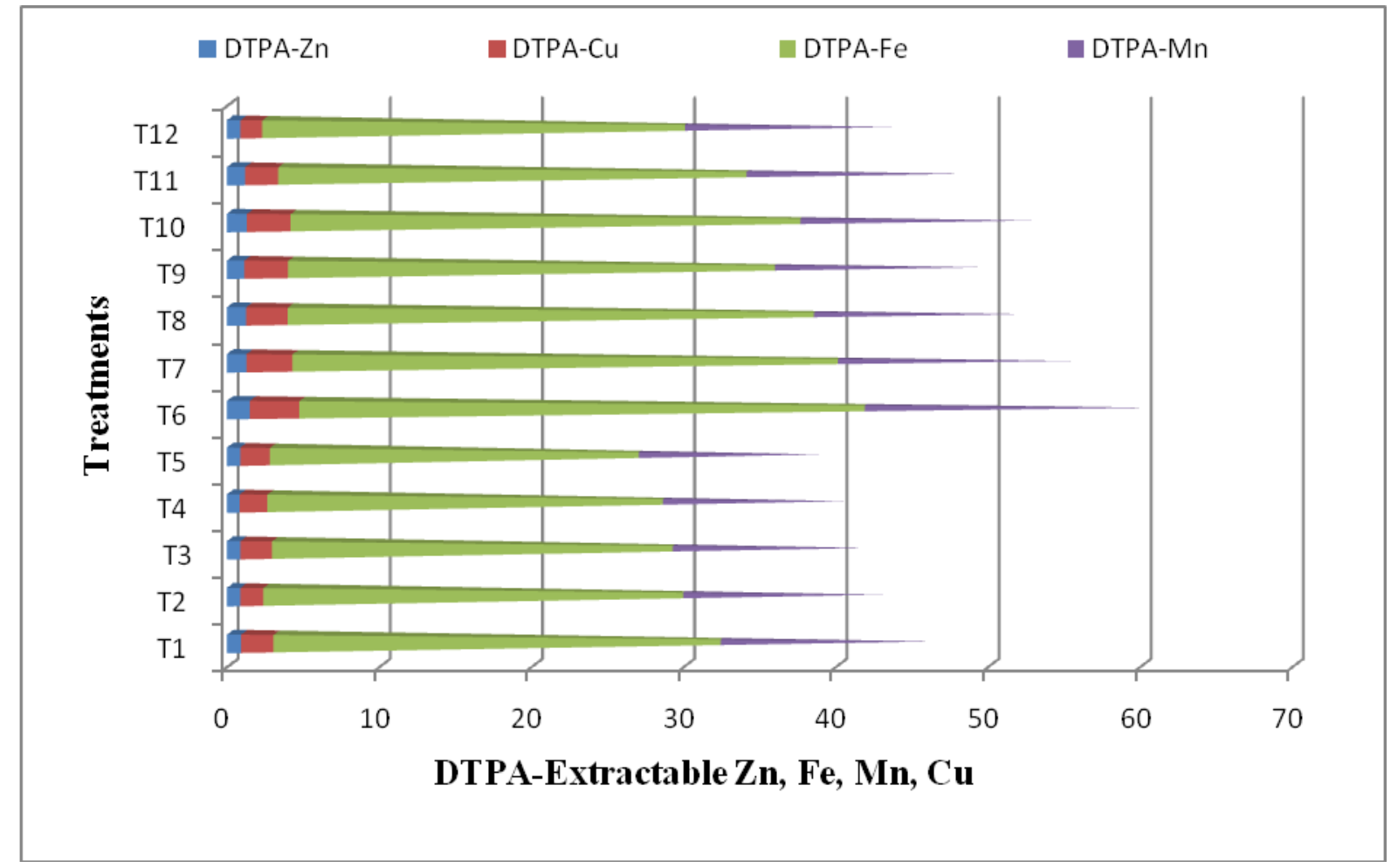




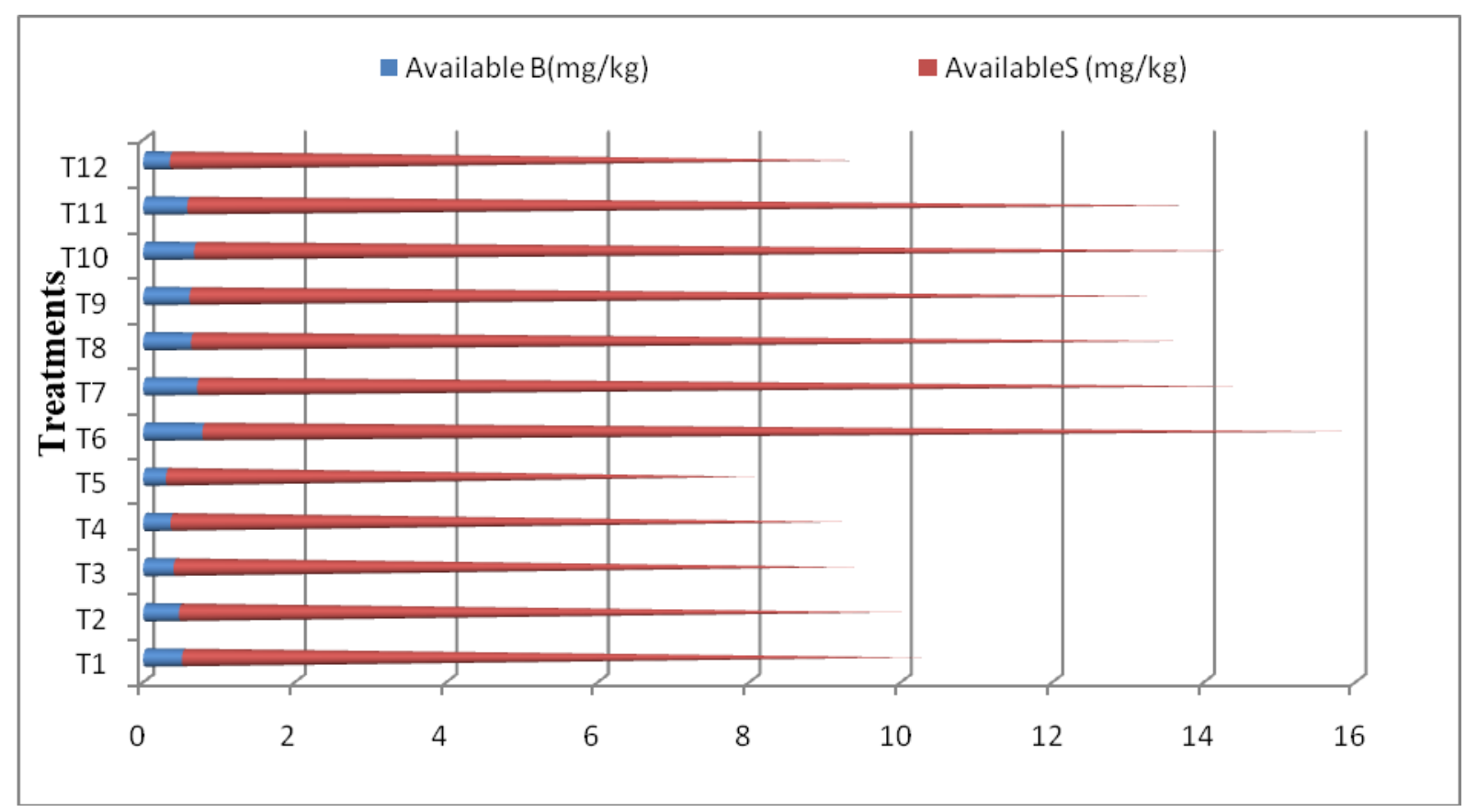

Organic manuring is another way to increase the Mn availability in soils. Its decomposition liberates a number of organic acids, lowers the soil reaction and increases the intensity of reduction in soil (Dhaliwal, 2008, Dhaliwal et al., 2019 and Walia et al., 2010).

\section{Available sulphur}

The available sulphur was significantly enhanced among different treatments is shown in table 3 . It was ranged from 7.78 to $15.16 \mathrm{mg} / \mathrm{kg}$ due to different treatments. The highest sulphur was recorded under $\mathrm{T}_{6} 15.16$ $\mathrm{mg} / \mathrm{kg}(50 \% \mathrm{~N}$ substituted with FYM in rice) which is statistically at par with $\mathrm{T}_{10}(13.83$ $\mathrm{mg} / \mathrm{kg}), \mathrm{T}_{7}(13.81 \mathrm{mg} / \mathrm{kg}), \mathrm{T}_{1}(13.34 \mathrm{mg} / \mathrm{kg}), \mathrm{T}_{8}$ $(13.12 \mathrm{mg} / \mathrm{kg})$ and $\mathrm{T}_{9}(12.83 \mathrm{mg} / \mathrm{kg})$ than $\mathrm{T}_{1}$ $(9.75 \mathrm{mg} / \mathrm{kg})$. Application of inorganic fertilizer (50, 75 and 100\% RDF farmer practices to both the crops) dose increased the available sulphur content in soil significantly decreased over control. It was recorded the data in $\mathrm{T}_{1}$-control $(9.75 \mathrm{mg} / \mathrm{kg})$ compared than $\left.\mathrm{T}_{2}(9.50 \mathrm{mg} / \mathrm{kg}), \mathrm{T}_{12}(9.10 \mathrm{mg} / \mathrm{kg})\right), \mathrm{T}_{3}$ $(8.96 \mathrm{mg} / \mathrm{kg}), \mathrm{T}_{4}(8.87 \mathrm{mg} / \mathrm{kg})$ and $\mathrm{T}_{5}(7.78$ $\mathrm{mg} / \mathrm{kg}$ ). Continuous growing of cereal crops without application of sulphur containing fertilizers caused decline in available ' $S$ ' in the soils compared to control (Shirale et al., 2013, Thakur and Sawarker, 2009). Similar result observed that Thakur et al., (2011) after 36 years under long term nutrient management. It might be possible that use of inorganic and organic fertilizer significantly increased available $S$ in soil because decomposition of organic matter and released organic acid in soil

\section{Available Boron}

The significantly changes in the status of soil available boron over a period of 34 years due to integrated nutrient management practices. The current study of available boron content in soil when harvesting of wheat crop increased from $0.30 \mathrm{mg} \mathrm{kg}^{-1}$ under treatment $\mathrm{T}_{5}-100 \%$ NPKto $0.78 \mathrm{mg} \mathrm{kg}^{-1}$ under treatment $\mathrm{T}_{6} 50 \%$ N-FYM. Review data in table (3) revealed that available boron in soil was noted significantly superior in $\mathrm{T}_{6}$ treatment due to different treatments combination and statically at par with $\mathrm{T}_{7}\left(0.71 \mathrm{mg} \mathrm{kg}^{-1}\right), \mathrm{T}_{10}$ $0.67\left(\mathrm{mg} \mathrm{kg}^{-1}\right), \mathrm{T}_{8}\left(0.63 \mathrm{mg} \mathrm{kg}^{-1}\right), \mathrm{T}_{9}(0.61 \mathrm{mg}$ $\left.\mathrm{kg}^{-1}\right)$ and followed by $\mathrm{T}_{11}\left(0.58 \mathrm{mg} \mathrm{kg}^{-1}\right)$ over $\mathrm{T}_{5}\left(0.30 \mathrm{mg} \mathrm{kg}^{-1}\right)$ where $100 \% \mathrm{NPK}$ was 
applied. All the treatment where $25 \%$ and50\% N-FYM, WS, GM along with inorganic fertilizers was registered higher available Boron in soil. Graded doses of chemical fertilizers also decreased the available boron contents in soil over control and graded dose of organic manure. Lowest available boron was recorded in $\mathrm{T}_{5}\left(0.30 \mathrm{mg} \mathrm{kg}^{-1}\right)$, All the treatments where $50 \%$ NPK, 75\% NPK, $100 \%$ NPK and farmer practices in both crops was applied through inorganic fertilizer showed lower available boron in soil compared to the $\mathrm{T}_{1}\left(0.51 \mathrm{mg} \mathrm{kg}^{-1}\right)$. FYM, GM, and WS are an important soil constituent affecting the availability of B. it is considered as the leading source of reserve B (Borax, 1998). It then replenishes the soil solution. Soil organic matter adsorbs more B than mineral soil $(\mathrm{Gu}$ and Lowe, 1990). The available B show a positive correlation with organic matter content (Saha et al., 1998).

\section{References}

Baker, B.J., Banfield, J.F., 2003. Microbial communities in acid mine drainage. FEMS (Fed. Eur. Microbiol. Soc.) Microbiol. Ecol. 44: 139-152.

Chesnin, 1., Yien, C.H. 1950.Turbidimetric determination of available sulphates. Proc. Soil sci. Am, 14:149-51.

Chouhan, B., Rai H.K., and Suryawanshi, A. 2017. Assessment of chemical properties of a Vertisol under long-term fertilizer experiment in soybean-wheat cropping system. International Journal of Chemical Studies, 5(6): 2107-2111.

Dang, Y.P., Verma, K.S. 1996. Nutrient management in sugarcane in Haryana State: Key to improved sugar production. In: Sugar cane research towards efficient and sustainable production. (Ed. Wilson, J.R., Hogarth, D.M., Campbell, J.A. and Garside, A.L.). CSIRO Division of Tropical Crops and Pastures, Brisbane, Australia, 203-205.

Dhaliwal, S.S., Manchanda, J.S., Walia, S.S. and Phutela, R.P. 2010. Nutrition management in maize (Zea mays L.)Potato (Solanum tuberosum L.)-Onion (Allium cepa L.) cropping sequence through organic and inorganic sources. Environ. Ecol. 28 (1):136-143.

Dhaliwal, S.S., Walia, S.S., 2008. Integrated nutrient management for sustaining maximum productivity of rice-wheat system under Punjab conditions. J. Res. Punjab Agric. Univ. 45, 12-16.

Dobermann, A. and Fairhurst, T.H. 2000. Rice nutrient disorders and nutrient management. IRRI / PPIC.pp. 3.

Gao, M., Che, F.C., Wei, C.F., Xie, D. T., Yang, J. H. 2000. Effect of long-term application of manures on forms of $\mathrm{Fe}$, $\mathrm{Mn}, \mathrm{Cu}$, and $\mathrm{Zn}$ in purple paddy soil. Plant Nutrition and Fertilizer Sciences 6: 11-17.

Govindaraj, M., Kannan, P.,Arunachalam, P. 2011. Implication of micronutrients in agricultureand health with special reference to iron and zinc. International Journal of Agricultural Management and Development 1: 207-20.

Gu, B., and Lowe, L.E., 1990.Studies on the adsorption of boron on humicacids. Can . J. Soil Sci. 70 (3), 305-311.

Hansel, C.M., Benner, S.G., Nico, P., Fendorf, S., 2004. Structural constraints of ferric (hydr) oxides on dissimilatory iron reduction and the fate of $\mathrm{Fe}(\mathrm{II})$. Geochem. Cosmochim. Acta 68, 3217-3229.

Johnston, A.E., Powlson, D.S., Greenland, D.J. and Szaboes, I. 1994. Soil resilience and sustainable land use CAB International, Wallingford, U.K, 367-393.

Kanwar, J.S., Randhawa, N.S. 1974. Micronutrient research in soils and plants in India: A review. ICAR Tech. Bull. (Agric.), 50: 1-60.

Lindsay, W.L. and Norvell, W.A. (1978). Development of a DTPA soil test for zinc, iron, manganese and copper, Soil Sci. soc. Am. J. 42:421-28.

Lindsay, W.L., 1988. Solubility and redox equilibria of iron compounds in soils. In: Stucki, J.W. (Ed.), Iron in Soils and Clay 
Minerals. Reidel Publ. NATO, Dordrecht, pp. 37-60.

Liu, W., Xu, X., Wu, X., Yang, Q., Luo, Y., Christie, P. 2006. Decomposition of silicate minerals by Bacillus mucilaginosus I liquid culture. Environ.Geochem.Health 28,133-140.

Mann, M.S., Takkar, P. N., Bansal, R. L. and Randhawa, N. S. 1978. Micronutrient status of soil and yield of maize and wheat as influenced by micronutrient and FYM application. Journal of the Indian Society of Soil Science, 26:208-214.

Mantovi1, P., Bonazzi1, G., Maestri, E., Marmiroli, N. 2003. Accumulation of copper and zinc from liquid manure in agricultural soils and crop plants. Plant and Soil 250: 249-57.

Mengel, K., 1994. Iron availability in plants tissues-iron chlorosis on calcareous soils. Plant Soil 165:275-283

Piper, C.S.1966.Soil and Plant Analysis, International Science Publication New York.

Ram, N. and Singh, V. 2005. Effect of 25 years of continuous fertilizer use on response to applied nutrients and uptake of micronutrients by rice-wheat-cowpea system. Cereal Res. Commun. 3:589-594.

Rupa, T.R., Tripathi, A.K., Rao, C.S., Singh, K.N. and Rao, A.S., 2001. Distribution and plant availability of soil copper fractions following copper sulphate and farmyard manure applications. J. Plant Nutr. Soil Sci. 164, 451-456.

S.S. Dhaliwal, S.S., Naresh, R.K., Agniva Mandal, A., Singh, R., M.K. Dhaliwal, M.K. 2019.Dynamics and transformations of micronutrients in agricultural soils as influenced by organic matter build-up: A review Environmental and Sustainability Indicators 1-2 100007.

Saha, J.K., Singh, M.V., Sharma, B.L., 1998.Available status of boron in major soil groups of Madhya Pradesh. J. Indian Soc. Soil Sci. 46 (3), 478-479.

Sahrawat KL. Importance of inorganic carbon in sequestering carbon in soils of the dry regions. Current Science.2003; 84:864-
865.

Sahrawat, K.L. 2003.Importance of inorganic carbon in sequestering carbon in soils of the dry regions. Current Science, 84:864865.

Sakal, R., Singh, A.P. 2001.Micronutrient in relation to response and quality of crop. Journal of Agricultural Chemistry, 14:45.

Satyavathi, P.L.A. 1998. Influence of structural condition of Vertisols on water relation characteristics Journal of the Indian Society of Soil Science. 46(1):129-132.

Sawarkar, S.D., Thakur, R. and Khamparia, R.S. 2010. Impact of Long Term Continuous Use of Inorganic and Organic Nutrients on Micronutrient Uptake by Soybean in Vertisol. J. Soils and Crops, 20 (2): 207-210

Sekhon, K.S., Singh, J.P., Mehla, D.S., 2006. Long-term effect of organic/inorganic inputon the distribution of zinc and copper in soil fractions under a rice-wheat cropping system. Arch. Agron Soil Sci. 52, 253-261.

Sharma, R.P., Kaushal, V., Verma, G. and Sharma, S.P. 2014. Effect of three decade long application of chemical fertilizer and amendments on crop yield under maize wheat cropping system in an acid alfisol. Journal of Applied and Natural Science, 6 (1): 106-109.

Shirale, S.T., Kide, D.S. and Meshram, N.A. 2014. Long-term effect of organic manuring and inorganic fertilizers for enhancing yield and soil propertiesx under soybean (Glycine max L.)safflower (Carthamus tinctoriusL.) cropping sequence in Vertisol. An Asian Journal of Soil Science, 9(1): 130-136

Singh, G., Jalota, S. K., and Singh, Y. 2007. Manuring and residue management effects on physical properties of soil under rice-wheat system in Punjab. Soiland Tillage Research 94:229-238.

Singh, M.V. 1988. Response of rice and wheat to phosphorus and zinc fertilization in sodic soils. Indian J. Agric. Sci., 58 (11): 823-827. 
Singh, M.V. 2001. Response of micronutrient to crops in different agroecological regions -experiences of AICRP Micronutrients. Fert. News, 42 (10): 43-49.

Singh, M.V. 2004. Micronutrients seed treatment to nourish the crop plants at critical stages of growth. Res. Bull., IISS, Bhopal, 2: 1-87.

Soni, M.L., Swarup, A., Singh, M. 2000. Effect of manganese and phosphorus application on yield and nutrition of wheat in reclaimed sodic soil.Current Agriculture 24,105-109.

Soriano-Disla, J. M., Gómez, I., NavarroPedreño, J., Lag-Brotons, A. 2010. Evaluation of single chemical extractants for the prediction of heavy metal uptake by barley in soils amended with polluted sewage sludge. Plant and Soil 327: $303-$ 14.

Subba, R.A. and Srivastava, S. 1998. Role of plant nutrients in increasing crop productivity. Fert. News 33 (4): 65-75.

Suzuki, A. 1997. Fertilization of rice in Japan. Japan FAO Association, Tokyo, Japan.

Thakur, R., Sawarkar, S.D., Vaishya, U.K. and Singh, M.2011.Impact of continuous use of inorganic fertilizers and organic manure on soil properties and productivity under soybean-wheat intensive cropping of a Vertisol. J. Indian Soc. Soil Sci., 59(1): 74- 81.

Thakur, R. and Sawarkar, S.D. 2009. Impact of Long Term Continuous Application of
Nutrients and Spatial Distribution of Sulphur on Soybean- Wheat Crooping Sequence. J. Soils and Use of Inorganic and Organic Nutrients on Micronutrient Uptake by Soybean in Vertisol. J. Soils and Crops, 20 (2): 207-210.

Tiwari, K.N. and Gupta, B.R. 2006. Sulphur for sustainable high yield agriculture in Uttar Pradesh. Ind. J. Fertilizers. 1: 37-52.

Walia, M.K., Walia, S.S., Dhaliwal, S.S. 2010. Long-term effect of integrated nutrient management of properties of TypicUstochrept after 23 cycles of an irrigated rice Oryza sativa L. - wheat Triticum aestivum L. system. Journal of Sustainable Agriculture. 34(7):724-743.

Walia, M.K., Walia, S.S., Dhaliwal, S.S. 2010. Long-term effect of integrated nutrient management on properties of TypicUstochrept after 23 cycles of an irrigated rice (Oryza sativa L.) - wheat (Triticumaestivum L.) system. J. Sustain. Agric. 34, 724-743.

Westfall, D. G., Mortvedt,J. J., Peterson, G. A., Gangloff , W. J. 2005. Efficient and environmentally safe use of micronutrients in agriculture. Communications in Soil Science and Plant Analysis 36: 169-82.

Wolf, B. 1971. The determination of boron in soil extracts, plant materials, composts, manures, water and nutrients solutions. Soil Sci. Plant. Anal. 2:363-374

\section{How to cite this article:}

Hena Parven, Sunil Kumar, Shweta Shambhavi, Sanjay Kumar, Raju Kumar and Dipti Kumari. 2020. Long Term Effect of Integrated Nutrient Management on Secondary and Micronutrient of Alluvial Soils. Int.J.Curr.Microbiol.App.Sci. 9(02): 1990-1999.

doi: https://doi.org/10.20546/ijcmas.2020.902.227 